\title{
Sermorelin Acetate
}

National Cancer Institute

\section{Source}

National Cancer Institute. Sermorelin Acetate. NCI Thesaurus. Code C47715.

The acetate salt form of sermorelin, a synthetic, amidated 29 -amino acid peptide that corresponds to the amino-terminal segment of the naturally occurring human growth hormone-releasing hormone (GHRH). Sermorelin acetate directly stimulates the pituitary gland, resulting in release of growth hormone leading to increased plasma growth hormone, which is responsible for many biological processes and counteracts growth hormone deficiency. 